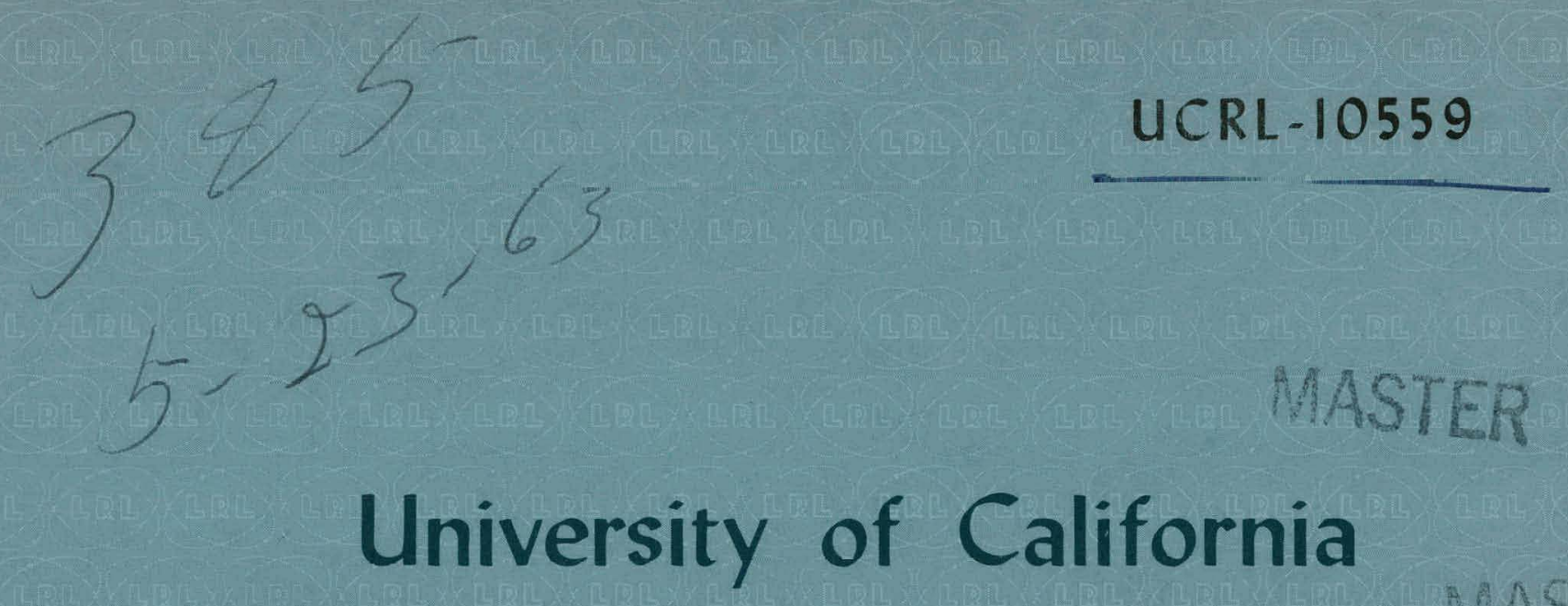

MASTER

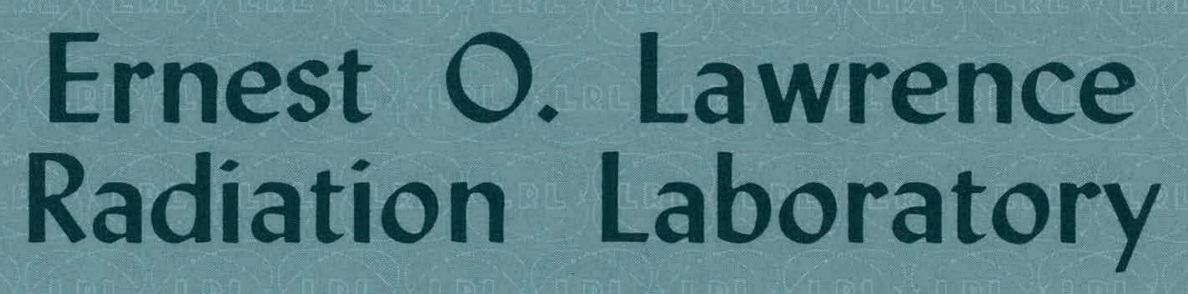

NEUTRON TISSUE DOSE AT LARGE DISTANCES

FROM AN ELEVATED UNSHIELDED REACTOR

Berkeley, California 


\section{DISCLAIMER}

This report was prepared as an account of work sponsored by an agency of the United States Government. Neither the United States Government nor any agency Thereof, nor any of their employees, makes any warranty, express or implied, or assumes any legal liability or responsibility for the accuracy, completeness, or usefulness of any information, apparatus, product, or process disclosed, or represents that its use would not infringe privately owned rights. Reference herein to any specific commercial product, process, or service by trade name, trademark, manufacturer, or otherwise does not necessarily constitute or imply its endorsement, recommendation, or favoring by the United States Government or any agency thereof. The views and opinions of authors expressed herein do not necessarily state or reflect those of the United States Government or any agency thereof. 


\section{DISCLAIMER}

Portions of this document may be illegible in electronic image products. Images are produced from the best available original document. 
UCRL - 10559

Heal th and Safety UC-41

TID -4500 (19. Ed.)

\section{UNIVERSI TY OF CALIFORNIA}

Lawrence Radiation Laboratory

Berkeley, California

Contract No. W-7405-eng -48

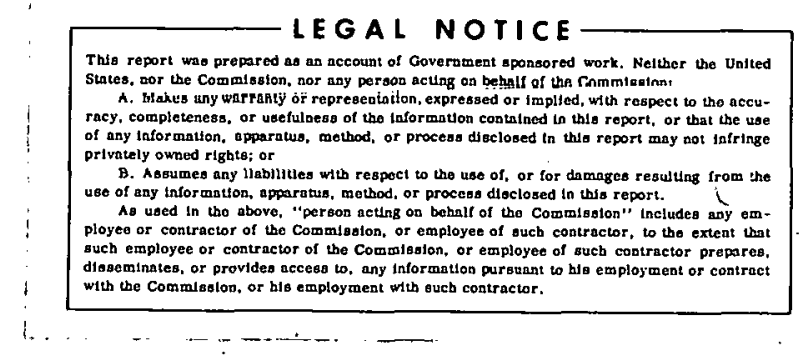

NEUTRON TISSUE DOSE AT LARGE DISTANCES FROM AN ELEVATED UNSHIELDED REACTOR

Henry Aceto, Jr., Michael A. Pick, and Lloyd D. Stephens

$\operatorname{March} 11,1963$ 


\section{THIS PAGE \\ WAS INTENTIONALLY \\ LEFT BLANK}




\title{
NEUTRON TISSUE DOSE AT LARGE DISTANCES FROM AN ELEVATED UNSHIELDED REACTOR
}

\author{
Henry Aceto, Jr, Michael A。 Pick, and Lloyd D。 Stephens \\ Lawrence Radiation Laboratory \\ University of California \\ Berkeley, California \\ March.11, 1963
}

\begin{abstract}
The neutron tissue dose at large distances from a fission source was studied by using a water-filled phantom and four different detectors: a $\mathrm{BF}_{3}$ counte $x$, a polyethylene-lined ethylene-filled proportional counter, indium foils, and nuclear emulsions. The source of fission neutrons was the ORNL Health Physics Research Reactor which was attached to a hoist which was in turn.installed on a 1530-foot tower. The reactor could be operated at any elevation from 27 to $1500 \mathrm{ft}$. The phantom studies were made at horizontal distances from 250 to 1500 yards from the tower. Dose contributions from recoil protons, $H^{l}(n, \gamma) D^{2}$ and $N^{14}(n, p) C^{14}$ reactions are considered.
\end{abstract}




\author{
NEUTRON TISSUE DOSE AT LARGE DISTANCES FROM \\ AN ELEVATED UNSHIELDED REACTOR* \\ Henry Aceto, Jr。 ${ }^{\dagger}$ Michael A。 Pick, and Lloyd D。 Stephens \\ Lawrence Radiation Laboratory \\ University of California \\ Berkeley, California. \\ March 11, 1963
}

\title{
INTRODUCTION
}

The neutron dose at large distances from a source is of interest at our laboratory because of the environmental neutron flux produced by the accelerators, especially the Bevatron。

If the variation of the neutron tissue dose through the body can be determined, it will be possible to evaluate the total neutron dose more precisely。

Our work is concerned with the neutron depth dose at large distances from an unshielded nuclear reactor. By using a variety of detectors we derived information as to the physical nature of the fast and thermal flus in the phantom and converted this to absorbed dose.

Other depth-dose studies have been done by Snyder and Neufeld; 1 Kogan, Petrov, Chudow, and Yampol'skii; ${ }^{2}$ Smith and Boot; ${ }^{3}$ and Aceto and Churchill。4

\section{APPARATUS}

\section{Phantom}

The phantom was an elliptical cyclinder $60 \mathrm{~cm}$ high, with a major axis of $36 \mathrm{~cm}$ and a minor axis of $20 \mathrm{~cm}$. It was made of $0.65-\mathrm{cm}$ polyethylene and was filled with water; it was supported by a $100-\mathrm{cm}$ wooden pedestal (Fig。 1)。 (It was found that the flux in the water-filled phantom was nearly the same as the flux in the phantom when it was filled with tissueequivalent fluid。) 4

\footnotetext{
* Work done under the auspices of the U.S.Atomic Energy Commission.

$\dagger$ Present address:University of Texas, Southwestern Medical School, Dallas, Texas。
} 


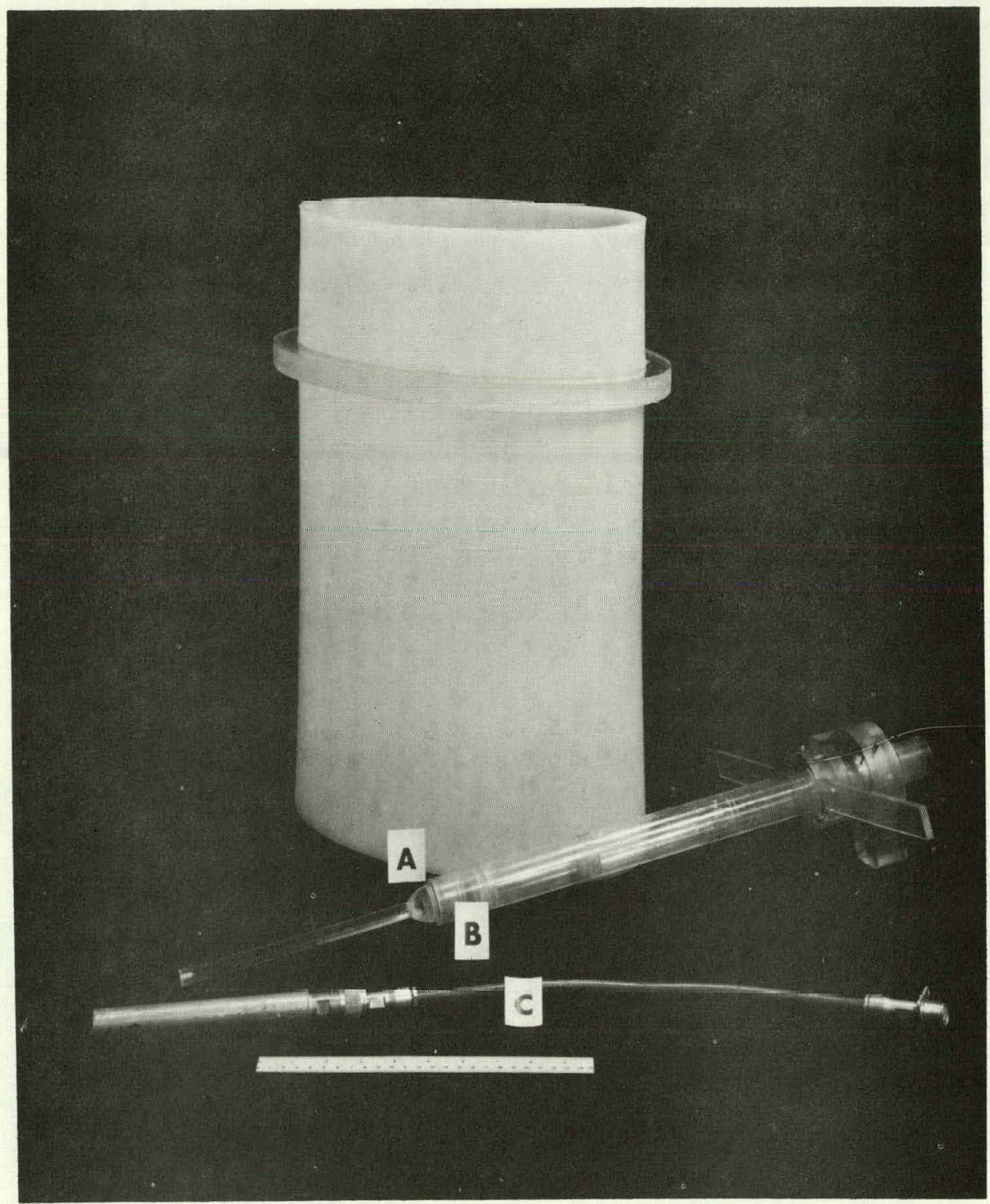

$\mathrm{ZN}-3630$

Fig. 1. (A) Phantom; (B) $\mathrm{BF}_{3}$ and polyethylene detector holder; (C) detector and cable to preamplifier. 


\section{Detectors}

Four detectors were used in the experiment: a $\mathrm{BF}_{3}$ counter, a polyethylene-lined ethylene-filled proportional counter, indium foils, and Ilford L-4 nuclear emulsions.

The fast neutron flux was measured by using the Ilford L-4 nuclear emulsions and the polyethylene counter.

The emulsions were scanned with a semiautomatic three-axis digitized microscope. The data were analyzed with an electronic computer. These devices have partly overcome the large amount of time required to collect and analyze data from nuclear emulsions. Unfortunately the sensitivity of the film changes rapidly 5 at energies lower than $0.5 \mathrm{MeV}$, and becomes insensitive to protons of energies lower than $0.4 \mathrm{MeV}$. Thus in a spectrum with an average energy of less than I MeV a large fraction of lower-energy neutrons will not be seen, thereby raising the apparent average energy to a value that we consider to be unrealistic. Due to this limitation the emulsions were not used to determine the average neutron energy.

The polyethylene counter, (Fig. 2) was calibrated by using a $\mathrm{Pu}-\mathrm{Be}$ source. This type of detector responds to gamma radiation as well as neutrons. Fortunately however, the gamma rays tend to produce smaller. pulses and can be discriminated against by proper bias-level settings. The response of this proportional counter is proportional to the energy flux.

The thermal flux was measured with a $B F_{3}$ counter (Fig。2) and indium foils. The foils were 0.005 in thick and weighed between 300 and $500 \mathrm{mg}$. They were mounted in a 0.007-in. depression in a thin lucite disk. After being activated by the thermal-neutron flux the foils were counted with a Geiger-Mueller tube 6 Both the $\mathrm{BF}_{3}$ counter and the indium foils were calibrated by using a concrete cube into which a neutron source had been placed. The walls of the cube act as a source of thermal neutrons; also, the thermal-neutron flux in the cube is uniform. 7 The expression for the experimentally derived thermal flux in the cube is

$$
\phi_{\text {th }}=1.26 \frac{\mathrm{Q}}{\mathrm{S}},
$$

where $\phi_{\text {th }}$ is the thermal flux in the cavity in neutron per $\mathrm{cm}^{2} / \mathrm{sec}_{\text {, }}$

$$
\begin{aligned}
& Q \text { is the source strength in neutrons/sec, } \\
& S \text { is the surface area of the cavity in } \mathrm{cm}_{0} 2
\end{aligned}
$$

The response of the indium foils and the $\mathrm{BF}_{3}$ counters to the the rmal flux in the phantom was not significantly different (see Fig. 8).

\section{Source}

The Health Physics Research Reactor used in BREN (Bare Reactor Experiment Nevada) was used as the source of neutrons. The reactor was fixed to a hoist mounted on a tower so that the reactor could be raised to 


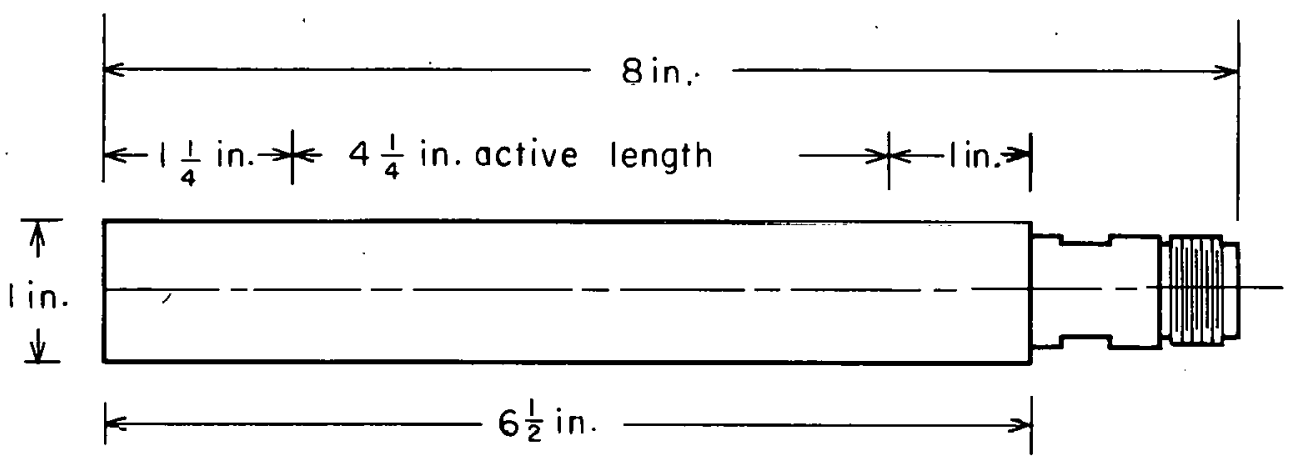

Body material 1100 aluminum

1/8 inch thick polethylene liner

Fill gas

Pressure $(\mathrm{cm}$ of $\mathrm{Hg})$

$\mathrm{BF}_{3} \quad\left(\mathrm{~B}^{10}\right.$ en riched) 60

Ethylene 76

$M U .27032$

Fig. 2. Detector dimensions. 
heights from 27 f to 1500 feet. The reactorwas operated at power levels up to more than. $1450 \mathrm{~W}$.

\section{METHOD}

The data were collected under varying conditions of reactor height, distance, and power levels on a noninterference basis with the Program. 1 experiment of Operation BREN.

The $\mathrm{BF}_{3}$ counter and the proportional counter were placed in a lucite holder (Fig。1) and immersed in the water in the phantom: (The lucite holder was found to have a negligible effect on counter response.) The surface meaisurements were taken with the counters held to the outside surface of the phantom. The position of the counters could be varied in a horizontal plane, but the vertical position was such that the center of the sensitive volume of the counter was $30 \mathrm{~cm}$ from the bottom of the phantom.

Indium foils were affixed to small lucite holders and exposed in the phantom in sets of 32 , consisting of 3 rows at 10 distances into the phantom, one foil on the front outside surface, and one foil on the back outside surface of the phantom. A flux-depression factor of 1.15 was used to correct for the "sink" effect of a foil on itself. 8 Also a correction of approximately. $5 \%$ was made for the sink effect of one foil on. another.

The Ilford L-4 emulsions were exposed in sets of seven: three were exposed.in the phantom, two on the outside surface (one in front, one in back), and one was exposed at a distance of $50 \mathrm{~cm}$ to the side of the phantomas a control. The remaining emulsion of each set was used to check the background. The presence of the emulsions is not expected to perturb the fastneutron spectra because the total macroscopic cross section of tissue and the emulsions are nearly the same. 5

\section{RESULTS}

\section{Dose from $\mathrm{N}^{14}(\mathrm{n}, \mathrm{p}) \mathrm{C}^{14}$ Reactions}

The depth dose from $\mathrm{N}^{14}(\mathrm{n}, \mathrm{p}) \mathrm{C}^{14}$ reactions can be calculated by merely using the collision density of thermal neutrons at the point in question. This is possible because the recoil proton expends its energy over a path only a few microns in length. Thus, for all practical purposes the energy is expended at the point of capture. The calculation is

where:

$$
D(z)=\phi_{\text {th }} \operatorname{QvN}\left(1.6 \times 10^{-8}\right) \text {, }
$$

$D(z)$ is the dose rate at a point in $\mathrm{rads} / \mathrm{sec}$;

$\phi_{\text {th }}$ is the thermal flux in neutrons per $\mathrm{cm}^{2} / \mathrm{sec}$

obtained by the $\mathrm{BF}_{3}$ counter or indium foils at

the point;

$Q$ is the energy of the proton, taken as $0.63 \mathrm{MeV}$;

$\sigma$.is the cross.section for the reaction, taken as

1. $75 \mathrm{~b}$; 
$\mathrm{N}$ is the nitrogen density in tissue, taken as $3 \%$

or $1.29 \times 10^{21}$ atoms $/ \mathrm{cm}^{3}$.

The results from the se calculations are shown in Figs. 3, 6, and 8.

$$
\text { Dose from } H^{1}(n, \sigma) D^{2} \text { Reactions }
$$

The gamma dose due to hydrogen.capture presents a greater problem in that the energy is not necessarily deposited near the site of the reaction. Using the formula by Taylor ${ }^{9}$ we can arrive at an approximate dose in the phantom:

$$
\begin{aligned}
D(z) & =f_{d}\left(E_{0}\right) \frac{S A}{2}\left[A_{1}\left(E_{1}\left[\left(1+a_{1}\right) \mu_{0} z\right]-E_{1}\left\{\left(1+a_{1}\right) \mu_{0} z\left[1+\left(\frac{R}{z}\right)^{2}\right]^{1 / 2}\right\}\right)\right. \\
& \left.+\left(1-A_{1}\right)\left(E_{1}\left[\left(1+a_{2}\right) \mu_{0} z\right]-E_{1}\left\{\left(1+a_{2}\right) \mu_{0} z\left[1+\left(\frac{R}{z}\right)^{2}\right]^{1 / L}\right\}\right)\right],
\end{aligned}
$$

where: $\quad D(z)$ is the gamma dose rate at $z$ along the perpendicular axis of a plane circularisotropic monoenergetic source uniformly distributed over a circle of radius $R$ in a homogeneous medium, $\mathrm{S}_{\mathrm{A}}$ is the specific source strength (gammas per $\mathrm{cm}^{2} /$. sec) put equal in turn to $S(z)$ for $z=0.5, z=1.5$, etc., $E_{1}(x)$ is $\int_{x}^{\infty} \frac{e^{-\xi}}{\xi} d \xi$, the first-order exponential integral, $A_{1}, a_{1}$, and $a_{2}$ are Taylor's energy-absorption buildup factors taken as $7.3,-0.065$, and 0.0488 , $\mathrm{u}_{0}=$ narrow-beam attenuation coefficient taken as $0.046 \mathrm{~cm}^{-1}$, $f_{d}\left(E_{0}\right)$ is the conversion from flux to dose, takcn as $2.226 \times 0.025 \times 1.6 \times 10^{-8}$, wherc 2.226 is the gamma energy in $\mathrm{MeV}$ and $0.025 \mathrm{~cm}^{-1}$ is the mass energy absorption coefficient.

Thus the gamma-ray dose at points through the phantom is calculated by numerically integrating the dose deposited by a series of slabs $1 \mathrm{~cm}$ thick by use of Taylor's formula, 3,9

The results of these calculations are plotted in Figs, 4, 6, and 8 .

\section{Recoil-Proton Dose}

The dose from the recoil protons was detcrmined by using the ethylene-filled polyethylene-lined proportional counter to measure the energy flux passing through a point in the phantom. The energy flux multiplied by the macroscopic cross section for an interaction gives the maximum energy 


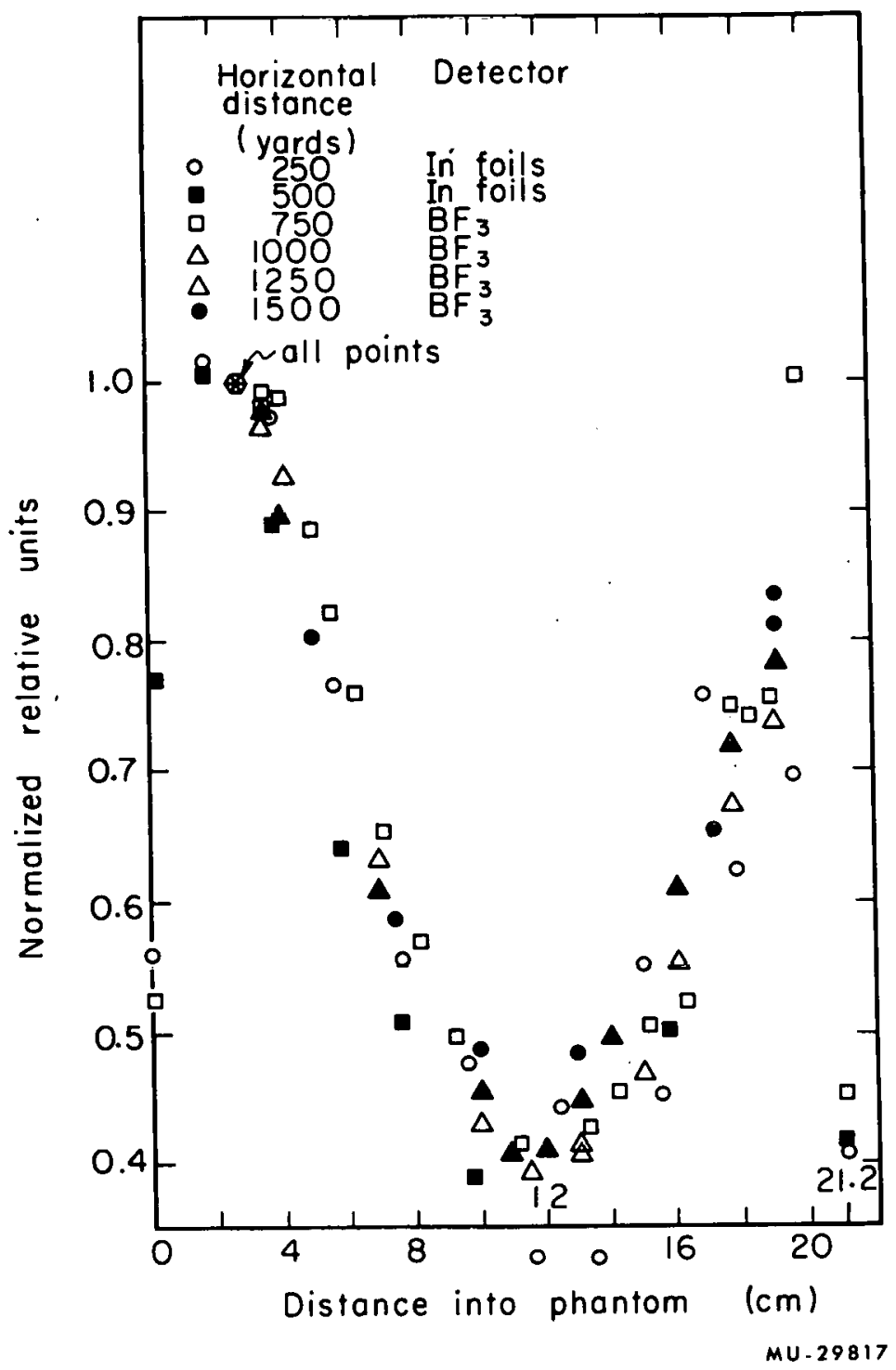

rig. 3. $\mathrm{N}^{14}(\mathrm{n}, \mathrm{p}) \mathrm{C}^{14}$ depth dose in phantom. 


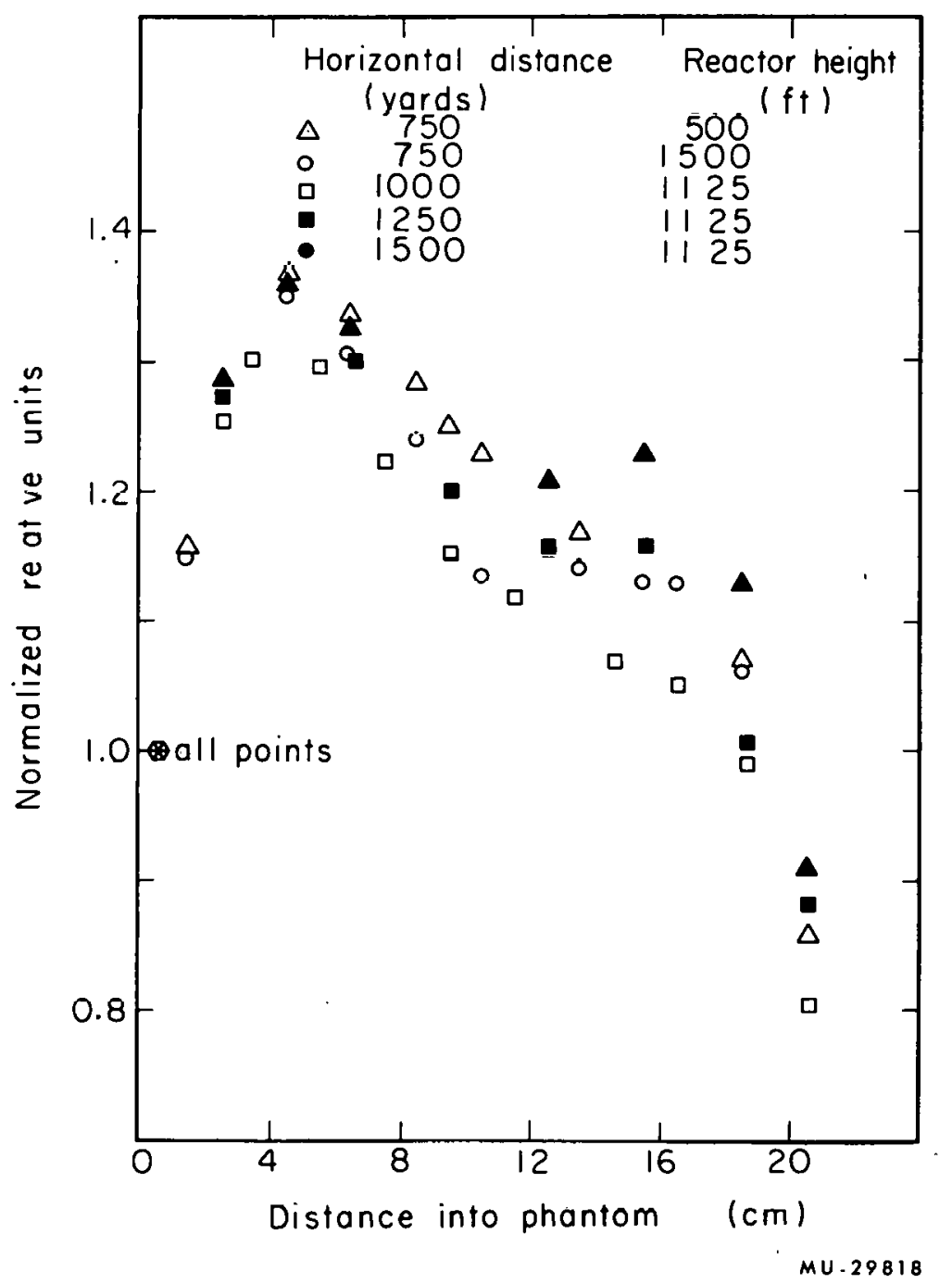

Fig. 4. $H^{1}(n, \gamma) D^{2}$ depth dose in phantom. 
deposition at the point. The average energy transfer in the $n-p$ collision is considered to be $\mathrm{E} / 2$. This leads to the following relationship for the recoil proton dose:

$$
D(z)=\operatorname{KNR} \sigma\left(8 \times 10^{-9}\right)
$$

whe re:

$\mathrm{D}(\mathrm{z})$ is the dose rate at point $\mathrm{z}$ in $\mathrm{rad} / \mathrm{min}$,

$\mathrm{K}$ is the calibration of the detector in $\mathrm{MeV} / \mathrm{cm}^{2}$,

N is the hydrogen density in tissue, taken as

$6.02 \times 10^{22}$ atoms $/ \mathrm{cm}^{3}$,

R is the count rate of the $P-E_{\text {th }}$ counter in counts per

min,

$\sigma$ is the cross section for an interaction at the average

impinging neutron energy

The factor $8 \times 10^{-9}$ comes from the consideration that the average proton recoil energy is just half the average neutron energy. The average neutron energy was obtained by using the ratio of the counts from a polyethylene-lined proportional counter and a paraffin-moderated $\mathrm{BF}_{3}$ counter。10 For the results from this calculation see Figs。 5, 6, and 8 .

\section{DISC USSION}

The shape of the dose curves suggest that the neutron field is nearly isotropic. This is esperially true for the thermal neutrons. The fact that the minimum of the curve for the recoil-proton dose is skewed toward the back of the phantom suggests that there is a fast-neutron component in the spectrum that is not entirely isotropic. This is to be expected, since these fast neutrons have not suffered as many scattering events, and they are not as randomly directed as the slow neutrons. The fact that the neutron field is nearly isotropic would mean that any given organ of the body will receive approximately the same dose regardless of the orientation of the body at the time of exposure.

\section{Dose from $N(n, p) C$ Reactions}

The dose from the $\mathrm{N}^{14}(\mathrm{n}, \mathrm{p}) \mathrm{C}^{14}$ reactions is a maximum very near the front of the phantom (see Fig. 3). The dose is a minimum very near the center of the phantom. Another fact that reinforces our belief in the isotropy of the neutron field is shown in Fig. 7: The dose in the center of the phantom shows only a slight variation as the major axis through the phantom is rotated from $90^{\circ}$ to $0^{\circ}$ to the reactor.

\section{Dose from $\mathrm{H}^{1}(\mathrm{n}, \mathrm{y}) \mathrm{D}^{2}$ Reactions}

The dose from $H^{l}(n, \gamma) D^{2}$ reactions are approximately a factor of 10 above the $N(n, p) C$ dose and about the same amount below the recoil proton dose (see Fig。 8). Also the gamma dose is much more homogeneous than the other two doses.considered, due to the fact that the energy is not generally deposited at the site of the reaction. 


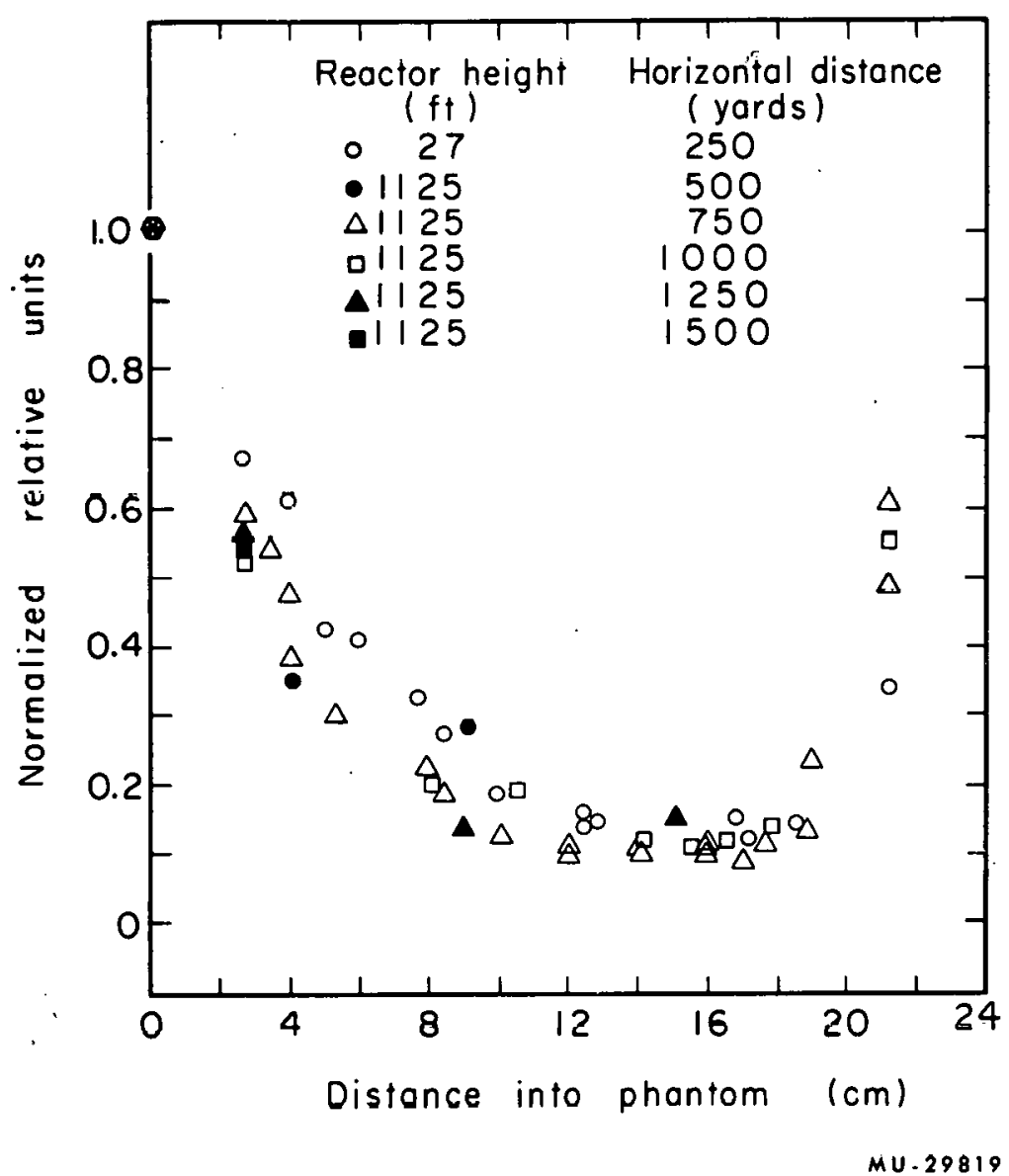

Fig. 5. Recoil-proton depth dose in phantom. 


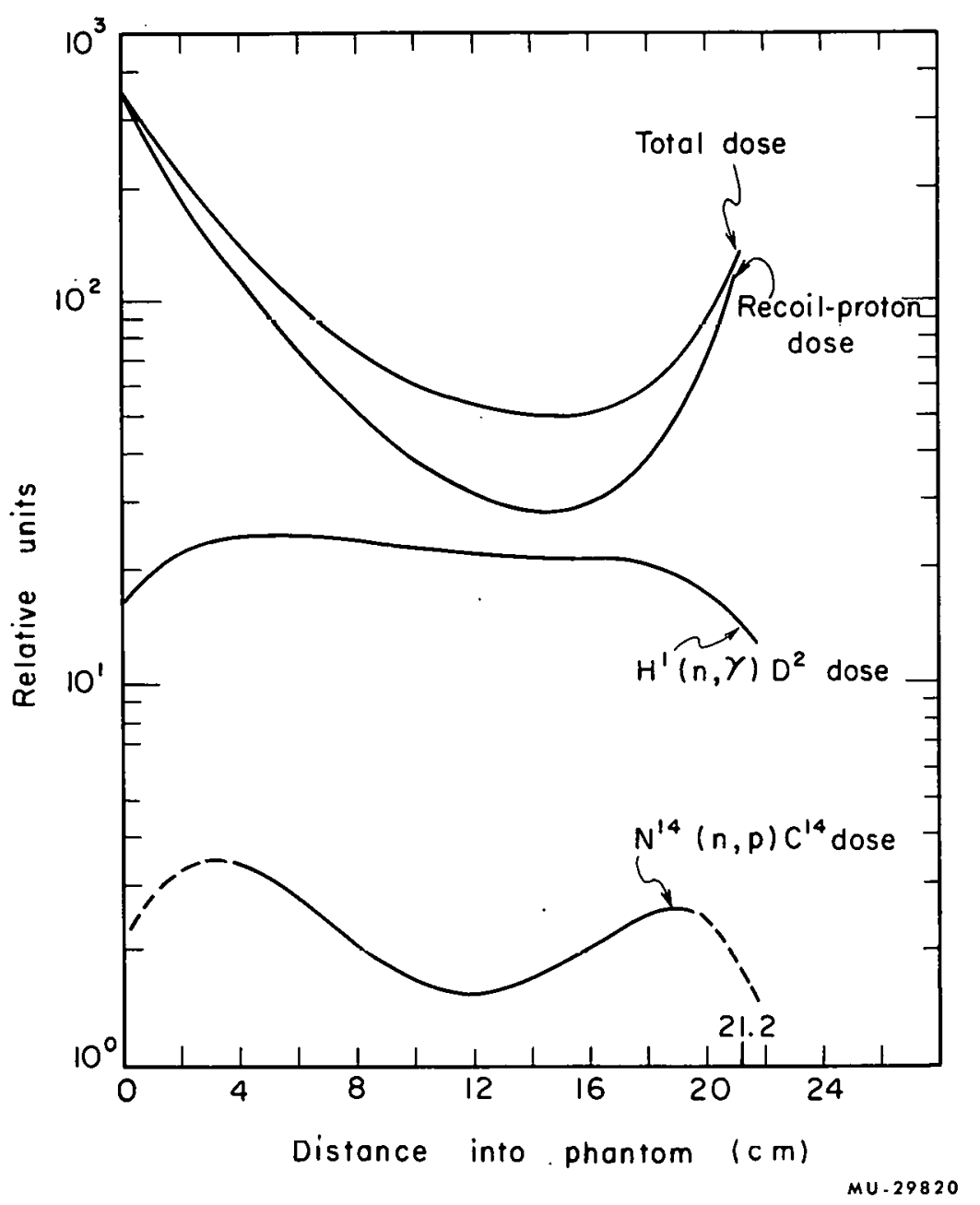

Fig. 6. Typical neutron depth dose in phantom. 


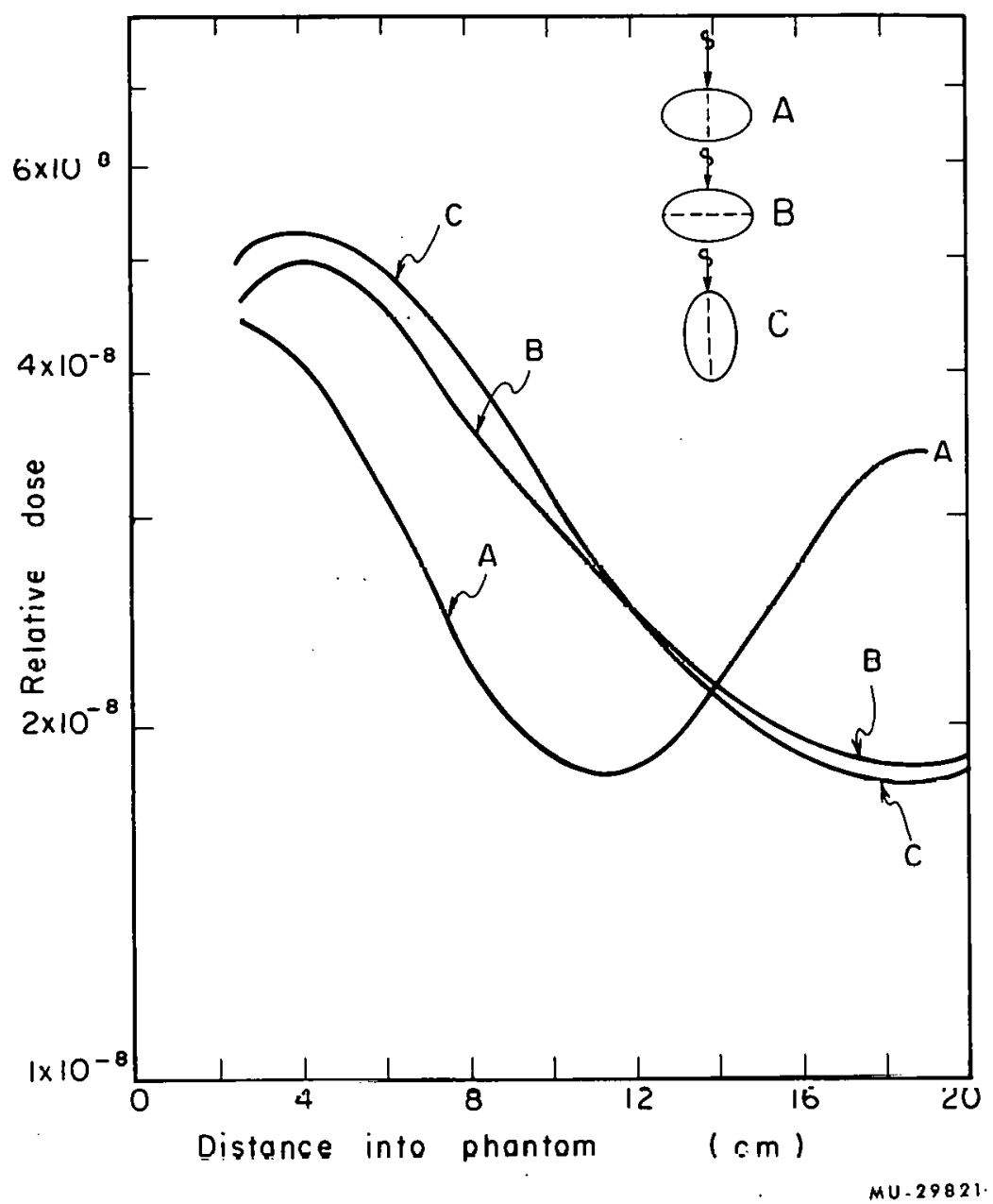

Fig. 7. Dose through phantom. (A) Dose along the minor axis with the minor axis facing reactor; (B) dose along the major axis with the minor axis facing reactor; (C) dose along the major axis with the major axis facing the reactor. All points taken at a distance of 1250 yards and reactor height of $1125 \mathrm{ft}$. 


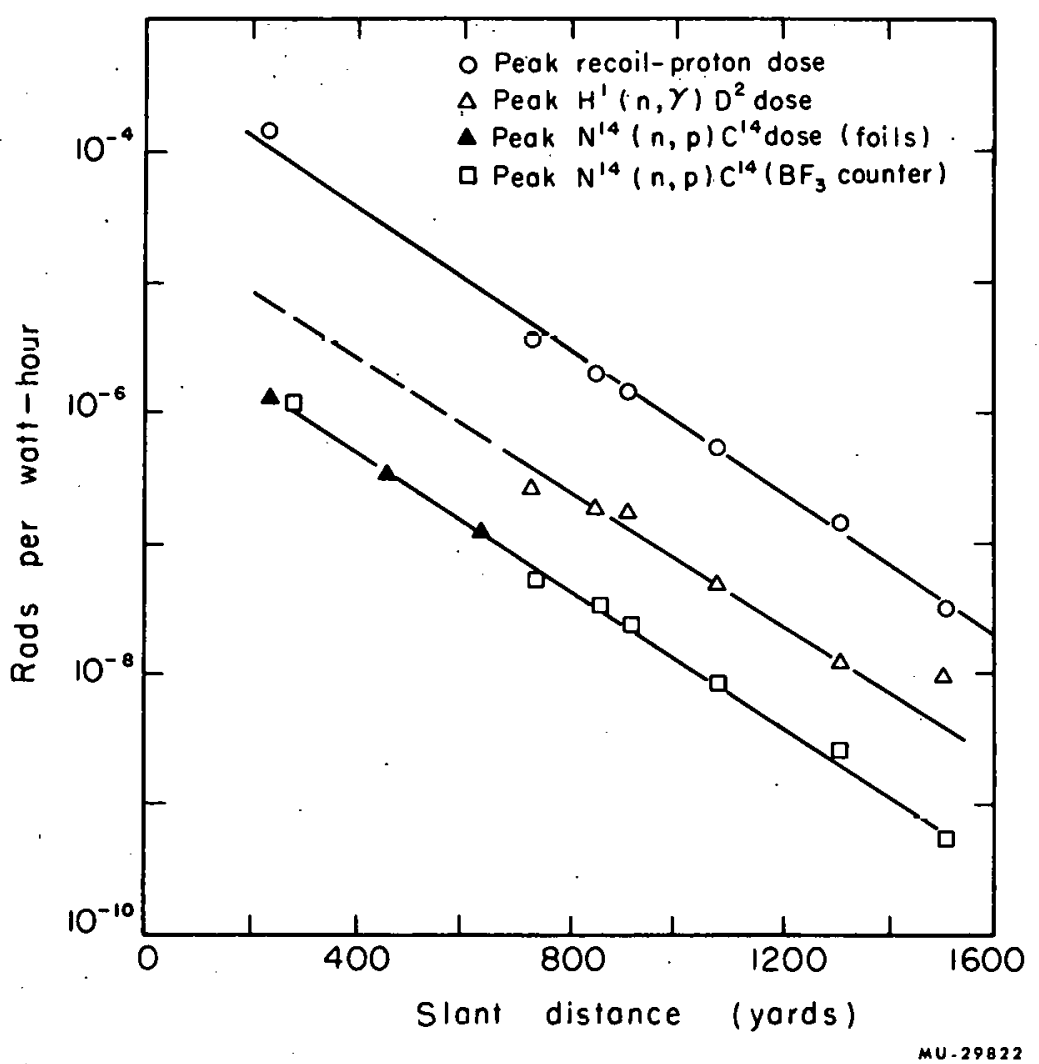

Fig. 8. Peak dose vs distance from reactor. 


\section{Dose from Recoil Protons}

The dose from recoil protons is subject to the assumption that the average energy of the neutrons does not change as they penetrate the phantom. Nuclear emulsions were to be used to test this assumption but they gave questionable results. Ever though the average neutron energy may change in the phantom it will not affect the reaction cros's section as much as may be expected. If the energy varies by a factor of two, the cross section will change by about $25 \%$. Still, our results should be considered as only approximations to the recoil-proton dose.

There are of course other recoils, especially with nitrogen, oxygen, and carbon atoms, but these collisions represent a small portion of the recoil dose and were neglected.

\section{SUMMARY}

The thermal-neutron flux can be considered as nearly isotropic at distances of 250 yards or more.

The fast-neutron flux can be considered as semiisotropic at distances greater than 250 yards.

The depth dose is shown.in Figs. 3 through 8.

\section{ACKNOWLEDGMENTS}

The authors are deeply indebted lo a large group of willing coworkers who helped in a variety of ways: We wish to thank:

$\mathrm{Mr} 。 \mathrm{H}_{\circ}$... Wade Patterson for his help and sirleve encouragement, which made our participation possible;

Miss Olga M. Fekula for the tedious work of scanning the emulsions;

Mr. R. L。 Corsbie, former Director, Civil Effects Test Operation, Division of Biology and Medicine, U.S.A.E。C。; Mr。L。J。Deal, Chief, Civil Effects Branch, and Mr。W.W. Schroebel, Civil Effects Branch, for their assistance and help in orientation and planning during the early stages of this program of Operation BREN;

Mr. John Williamson and his staff of the Reynolds Electric and Engineering $\mathrm{Co}_{\circ}$, for their support given us at the Nevada Test Site;

Mr。 Tom Brockett and $\mathrm{Mr}$ 。 Don Schuler of.Lawrence Radiation Laboratory, Nevada, for their support of our experimental needs throughout the entire time we spent in Nevada.

We are especially indebted to Mr. John Auxier, Mr。Fred Sanders, and Mr。 Fred Haywood of the Health Physics Divisior, Oak Ridge National Laboratory, who invited us to participate in this undertaking. Further, they gave their wholehearted encouragement to us as the experiment progressed. 


\section{REFERENCES}

1. W. S. Snyder and J. Neufeld, Calculated Depth Dose Gurves in Tissue for Broad Beams of Fast Neutrons, Brit. J. Radio. 28, 342 (1955).

2. A. M. Kogan, G. G. Petrov, L. A. Chudov, and P. M. Yampol'skii, The Neutron Tissue Dose, Soviet J。At。 Energy (English Transl。) ?, 830 (1961):

3. J..W. Smith and S. J. Boot, The Variation of Neutron Dose with Depth in a. Tissue-Equivalent Phantom, Phys。 in Med。 Biol。 7, 45 (1962).

4. H. Aceto, Jr。 and B. W. Churchill, Neutron Depth Dose from (a, n) and $(\gamma, n)$ Sources in a Tissue-Equivalent Phantom, UCRL-10267. March 1963 (unpulvlished).

5. H. Akagi and.R. L. Lehman, Neutron Dosimetry in an Around Human Phantoms by Use of Nuclear Track Emulsion, UCRL-9967 Rev。, June 1962 (unpublished).

6. L. D. Stephens and.A. R. Smith, Fast Neutron Surveys Using Indium Foil Activation, UCRL-8418, August 1958 (unpublished).

7. H. W. Patterson and.R. Wallace, A Method of Calibrating Slow-Neutron : Betectors, University of California Radiation Laboratory Report UCRL-8359, July: 1958 (unpublisher).

8. C. W. Tittle, Slow Neutron Detection by Foils, Nucleonics:9, 60 (1951).

9. J. J. Taylor, Application of Gamma Ray Buildup Data to Shield Design, Westinghouse Electric Corp. Report WAPD-RM-217, (unpublished)。

10. L. D. Stephens and H. Aceto, Jr。, Variation of a Fission Neutron Flux and Spectrum.from.a. Fast Reactor Measured Over Large Distances, Lawrence Radiation Laboratory Report UCRL-10361, October 1962 (unpublished). 
This report was prepared as an account of Government sponsored work. Neither the United States, nor the Commission, nor any person acting on behalf of the Commission:

A. Makes any warranty or representation, expressed or implied, with respect to the accuracy, completeness, or usefulness of the information contained in this report, or that the use of any information, apparatus, method, or process disclosed in this report may not infringe privately owned rights; or

B. Assumes any liabilities. with respect to the use of, or for damages resulting from the use of any information, apparatus, method; or process disclosed in this report.

As used in the above, "person acting on behalf of the Commission" includes any employee or contractor of the Commission, or employee of such contractor, to the extent that such employee or contractor of the Commission, or employee of such contractor prepares, disseminates, or provides access to, any information pursuant to his employment or contract with the Commission, or his employment with such contractor. 